\title{
THE AUTHENTICITY OF HADITH NARRATED BY NAFI' THE MAWLA OF IBN 'UMAR
}

\author{
Abdul Hakim Wahid \\ Syarif Hidayatullah State Islamic University (UIN) Jakarta \\ hakim.wahid@uinjkt.ac.id
}

\begin{abstract}
Nafi' the mawla of Ibn Umar, the hadith narrator in the group of Asah al-Asanid is considered the unhistorical person and the traditions narrated by him are unaccountable because he does not qualify as a common link in the view of Juynboll. This article tries to prove the authenticity of traditions narrated by Nafi' by taking a sample from the alSahihayn book and making an isnad bundle of its, in order to know the position of Nafi' in the transmission of those traditions. After all samples were examined, it was found that Nafi' and the narrator above him could be qualified as a common link, so it is concluded that Nafi' narrations are authentic with this evidence.
\end{abstract}

Keywords: Authenticity, Nafi', Hadith, Isnad, Common link.

\section{Introduction}

In the theory of isnad analysis developed by Juynboll, a hadith can be considered to have historical value if narrated by a common link, he is who has two or more pupils and they also have two or more pupils too (Juynboll, 1985). This theory based on the assumption that more narrative channels which meet a narrator, both toward him and also leave him, so the hadith narrator has a more historical claim. According to this theory, a hadith is acceptable not only by narrator quality but the most important is on its narrator quantity (Masrur, 2007).

By applying that theory in several of his articles, Juynboll has made the conclusion of fake thousands traditions contained in the canonical book narrated by Nāfi' the mawla of Ibn Umar, a narrator in the group of Așah al-Asānìd, and one of isnad dhahabiyyah-golden chain (Ibn Șalāh, 1986 ), because according to Juynboll, Nāfi' is never really a common link, but only a seeming common link, while the predicate as the real common link in the traditions relied on him is his pupil Malik bin Anas (Juynboll, 1996), and also because of Nāfi' the mawlā of Ibn 'Umar personality which is very little in the biographical book (Juynboll, 2007). Then, followed Schacht's opinion (Schacht, 1950), Juynboll said that Nāfi' is just a name that is often inserted in an isnad to make one tradition has more authority, whereas Nāfi' is actually a fictitious person. Therefore, Juynboll concluded that all hadiths with the chain of Nāfi' in the six books (kutub sittah) which amounted to 1088 hadith (Amin, 2009), can not be accounted as authentic. Juynboll's final conclusion on this common link issue is the stipulation that the common link is a fabricator or originator who spread the hadith extensively for the first time.

The Juynboll's common link theory is the development of Joseph Schacht's theory which had previously been rebutted by Mustafa 'Azami in his book On Schacht's Origins of Muhammadan Jurisprudence, but according to contemporary scholars, Azami's argument is still considered less powerful, Because Azami who tried to show the false of Schacht's conclusion by revealing the isnad chain of 'Amr bin Abi 'Amr (Azami, 2004), apparently according to Ali Masrur, resulted in the opposite actually, that is empowering Schacht's opinion of the existence of common link theory (Masrur, 2007). Juynboll's conclusions have also been heavily disputed by other Muslim scholars, but 
from a number of refutations, no one has focused on strengthening Nāfi's transmission. The rebuttal specifically related to the case of Nāfi' the mawla Ibn Umar was done by Harald Motzki.

Motzki attempted to counter Juynboll's argument by using the Muṣannaf Abd alRazzāq al-Șan'ān̄ with his Isnad cum Matan analysis Theory. Then in Analysing Muslim Tradition: Studies in Legal, Exegetical and Maghazi Hadith book, he presented his commentary on several conclusions of Joseph Schacht and GHA Juynboll in the study of hadith in a straightforward manner and pointed out some of Schacht and Juynboll's wrongs in their research, from references taken and generalization processes which is conducted. Furthermore, by looking at the variations of the word form in the hadith of the zakat fitrah narrated by Nāfi', which is conveyed with various variations, some use the word "Amara", and some use the word "Farada" or "Qala", Motzki concludes that those words indicate the authenticity of the original source, because the hadith narrators did not change the sentences of transmission (Motzki, 2010). Nevertheless, according to the author of this paper, this argument still can be rebutted by Juynboll's colleagues with the theory of "back projection" or the existence of a matanic changing by the canonical authors, even Reinhart concluded that there is no contemporary scholar has been able to reject the arguments of Juynboll (Reinhart, 2010). For this reason, this study is very important, considering that the present arguments are still not strong. In this article, the author will reveal evidence that majority of hadiths narrated by Nāfi' can be considered as authentic.

\section{Methods}

Looking at the conclusion of the false traditions on Nāfi' the mawla of Ibn Umar transmission line which is very much, this article attempts to compare Juynboll's findings with the facts in the hadith literatures to prove the truth of his claim that Nāfi' is not a common link by examining the traditions contained in the two book; Sahih Bukhari and Sahih Muslim. The theory used by the author is the Juynboll's common link theory modified with the theory of testimony as according to Islamic tradition, must have two witnesses in every sale and purchase or accounts payable. It is used because it also applied to other religions which require two witnesses in marriage. Therefore, as a condition for Nāfi' to become a common link (furthermore it be abbreviated as CL) is if he has two or more disciples and they have two or more disciples as well, so the status of the two students is a Partial Common link (furthermore it be abbreviated PCL). The requirement of Nāfi' to have PCL only to the extent of his disciples only, and not necessarily to the compilers of the hadith, because with the evidence of hadith spreading to two or more persons at the level of Nâfi'disciples has proved that the path of narration of the hadith is not a single path and indicates the spreading of hadith in early Islam.

Although it has not been able to comply with the requirements of Juynboll in Common link theory that the last refined in terms of real common link (rcl) and real partial common link (rpcl), however, this theory does not violate the basic provisions of the Schacht's common link theory and modified by Juynboll, because he just doubts the impossibility of one person passing on to one more person to the collector of the hadith. According to him, this phenomenon is not a coincidence, but it is an attempt to authenticate the hadith during the birth of isnad (Juynboll, 2001). The main of his point is how did the compilers of the hadith can only quote the writings of one teacher, or simply find a matan with the single path of the teacher (Juynboll, 1996). In his theory, Juynboll said that in the hadith isnad bundle, there is always a narrator who became the key figure in the hadith spreading. The narrator is described as having spread the hadith to some disciples, or there are some people delivering news from a teacher to the next generation, 
or to a person, such a transmission can be easily believed to have a historical value, and the person is given a status as $C L$. Juynboll did not mention the main reason for making the provision that caused a $C L$ to have some students who then called PCL. He just said that the sensible transmission is only which come from a CL disciple who also has several disciples (Juynboll, 1996). Thus, the common link theory that the author applies in this study, does not violate the main provisions of Juynboll theory.

To obtain a strong argument, the author have chosen 66 of the 188 hadiths with the path of Nāfi' narrations selected randomly and written in two Sahih al-Bukhari and Muslim. With regard to the assessment of the predicate of the narrator, the writer follows Ibn Hajar's opinion in order to predicate them. The reason is that Juynboll also acknowledges and used Ibn Hajar's opinion in determining his argument, so this source is considered as valid for used in generalizing the final conclusion.

\section{Result and Discussion}

After all traditions are examined and it's bundle isnad made, apparently obtained five categories of hadith. First, the tradition whose common link is Nāfi'. Second, hadiths with Ibn Umar or another companion as a common link. Third, hadiths with CL status bears the Prophet. Fourth, hadith which has CL of tabi'in at one tabaqah (level or lifetime) with Nāfi'. And Fifth, hadiths which have no CL in the isnad bundle.

The results of the research have been done, to find a number of hadiths with the position of Nāfi' to qualify as a CL as specified by Juynboll. The assumption that he is just seeming common link is inappropriate. On the case of hadith of Zakat fitrah which Juynboll studied, he further concludes that Nāfi' is only a seeming common link, the author find an oddity in the analysis he has used, because in fact in the isnad bundle, Nāfi' is qualified as CL. The following is the diagram of zakat fitrah hadith isnad bundle made from kutub sittah:

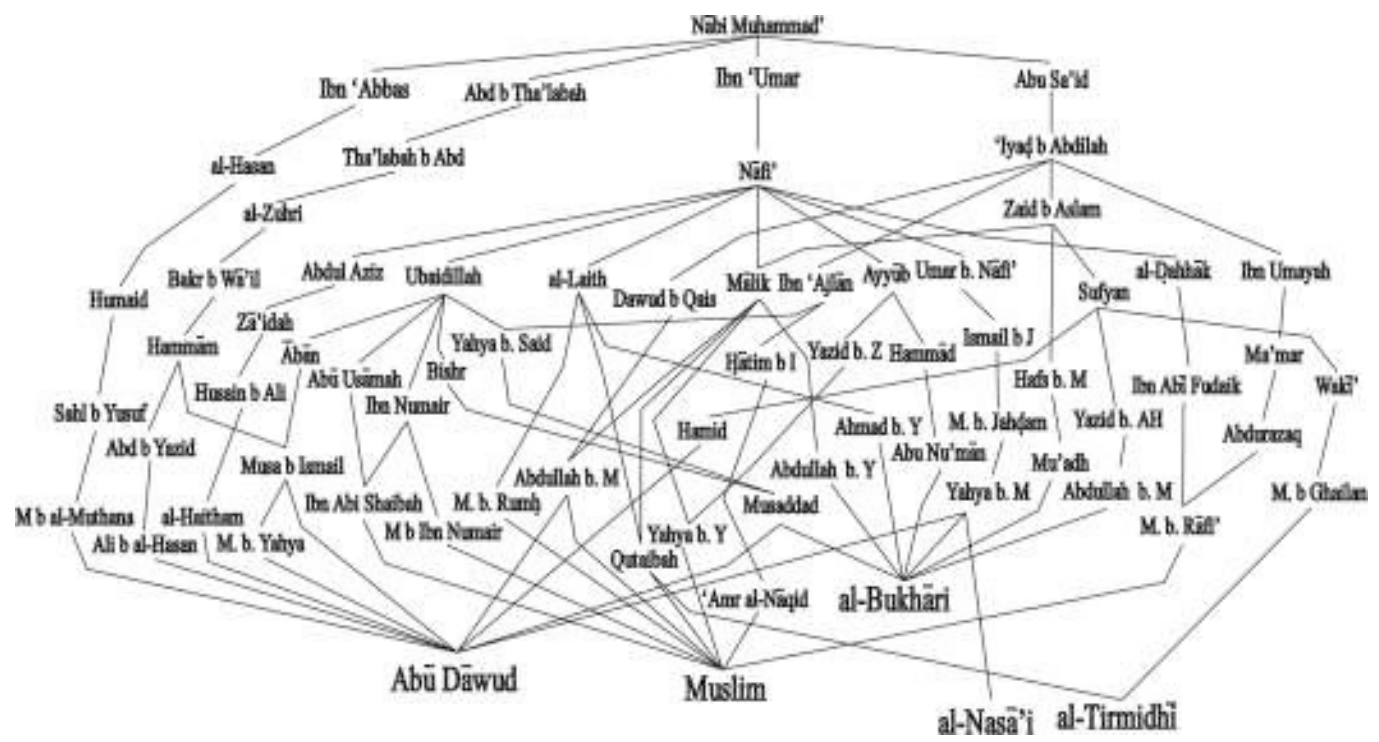

In his article, Juynboll explained each narration path of hadith from different Nāfi' disciples. Starting with the path of al-Laith which actually qualified as PCL because he has three pupils: Ahmad bin Yunus, Qutaibah bin Sa'id and Muhammad bin Rumh. The last two names have delivered the hadith to two or more pupils, so al-Laith was qualified as PCL for the Nāfi'. Yet Juynboll abandoned the PCL status of al-Laith only because of Ibn Ma'in's commentary that al-Laith was Thiqat Salih (Ibn Hajar, 1326). 
That commentary according to Juynboll, was an expression of something that must be doubted, whereas, in al-Jarh wa al-Ta'dìl science, the meaning is not as he understood. Juynboll also considered that Muslims have made a false isnad in the path of his transmission from al-Laith, but by following Motzki's opinion, the author see that Muslim honesty in his narration. That honesty is known from a sentence of narration that he revealed from his teacher. For example, in conveying the narration of Qutaibah, Muslims said: Haddathana Qutaibah, $H$ addathan $\bar{a}$ al-Laith, while Muhammad bin Rumh's, he revealed with the phrase: Haddathanā Muhammad bin Rumh, Akhbaranā alLaith (Muslim, 1993). From those idioms can be deduced that the two pupils of al-Laith actually met him and conveyed to Muslim with their respective expressions, so this path is very strong in supporting the authenticity of the hadith narrated by Nāfi'.

Similarly, in the transmission line of Ubaidillah bin Umar who spreads the hadith to 5 students, with 2 of them are qualified as a PCL, but Juynboll only recognized the line of Yahya bin Said, which he said deliberately made by Musaddad. Whereas Ibn Numair's path that should qualified as PCL is rejected simply because one of his students is the category of the family isnad transmission, there for Juynboll alleged that Muslim bin alHajjāj or his teacher has made this path to corroborate the hadith.

Furthermore, Ayyub as a disciple of Nāfi' actually fulfilled his status as PCL, but it was canceled by Juynboll because the two paths beside Hammad were a single strand, and the existence of Hammad was on the path with the specific purpose of elevating Ayyub as hadith fellow from Basrah. So it can be said that Juynboll accused Hammad of falsifying this path for other purposes, and these accusations follow Joseph Schacht's unproven findings.

On the same occasion, Juynboll gave an expression that according to opinion considered as a gaffe, One of that is his statement that shows Juynboll inconsistency in assessing the transmission path of hadith. On one transmission, he considered an uninterrupted path, but in other narratives he deemed invalid with unfavorable arguments (Juynboll, 1996), whereas the narrative routes are of the same shape, but the judgment against them is not the same as those of various aspects which he call as the motive analysis, so the author see his efforts in attempt to undermine Nāfi's status as CL, with his judgment on Nāfi'students, in order that they cannot be qualified as PCL. To show the authenticity of Nāfi's transmission below is one of the isnad bundle which can prove that the Prophet is qualified as CL:

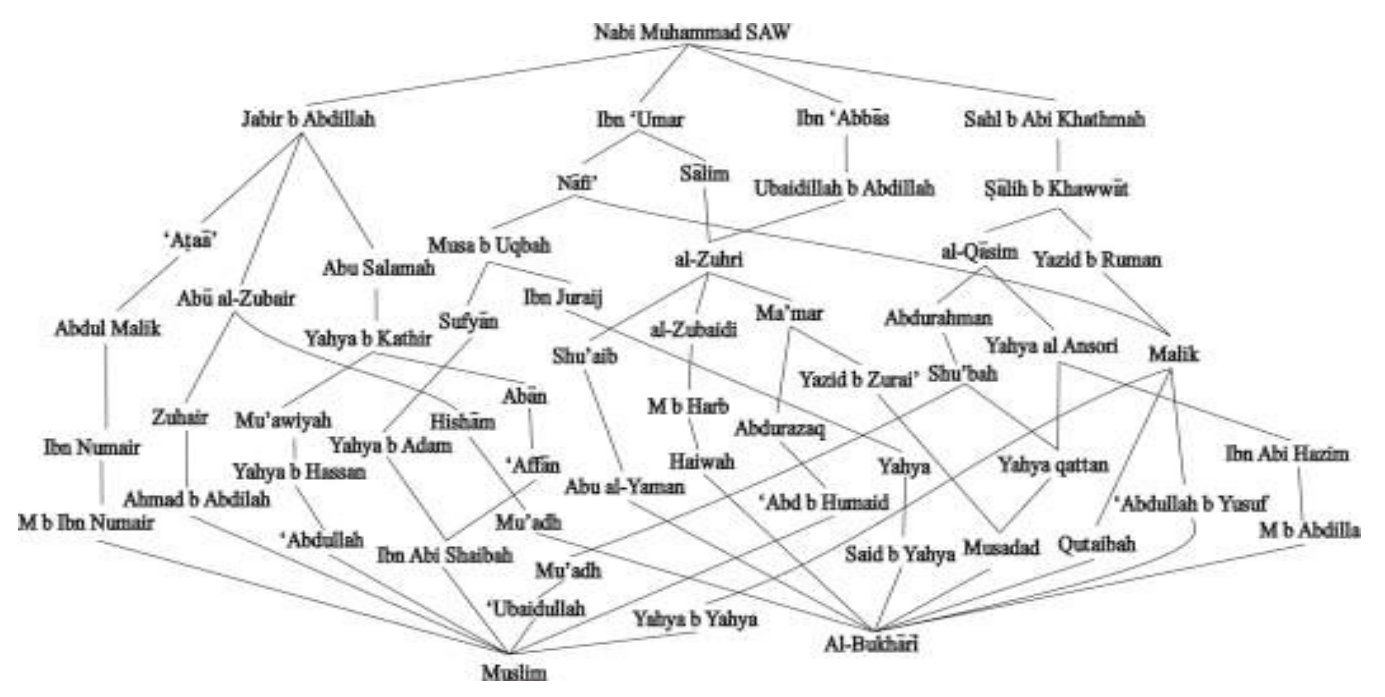


The isnad bundles constructed based on the entire transmission line in two valid books that speak of the khawf prayer as practiced by the Prophet, illustrated that there were 4 Companions who witnessed the event, two of them convey information to a student and 2 others deliver to 2 or more students then the status of the two companions; Ibn Umar and Jabir Ibn Abdillah is PCL and the Prophet is CL in this hadith. Thus this hadith can be authenticated, even though there is one Jabir path identified as "diving", but two of his other disciples qualified a PCL. The position of Nāfi' in this isnad bundle is a PCL, because he spread the hadith to his two students; Musa Ibn 'Uqbah who spread the hadith to two students, and Malik Ibn Anas who spread to his three pupils. These two paths of Nāfi' are recorded in two valid books.

\section{Conclusions}

This article shows that with an in-depth analysis on Nāfi's narrations contained in the al-Sahīhayn literature, proves that Juynboll's conclusions are not entirely correct. A total of 1088 traditions contained in the six literatures (kutub sittah) with the chain Nāfi' Mawla of Ibn Umar which have been deemed to have no historical value or with abusive language are called false hadiths, after being investigated have a better path. In some isnad bundles, Nāfi' is found as a common link, Ibn Umar, the teacher of Nāfi' was also found to be a real common link, even there are some traditions whose common link is the Prophet. This found proof can be used to generalize that the majority of the hadiths with the narrative path of Nāfi' from Ibn Umar in the al-Sahinhayn book are authentic. This article also proves that there is a misunderstanding of Arabic texts used by Juynboll as an argument for reinforcing his opinion. Thereby, this proves also reinforcing Harald Motzki's opinion that Juynboll is always trying hard to find a strong argument, therefor he often invokes insufficient references.

The author of this article uses 66 hadiths as research samples taken with the selection of simple random sampling. This amount is derived from the population of 188 hadith narrated by Nāfi' which is contained in the al-Sahīhayn book. After all hadith is researched and its isnad bundle made, obtained 5 categories of hadith as follows: (1) Hadith that its common link is Nāfi', as many as 20 hadith $=30,3 \%$. (2) Hadith with Ibn Umar as a common link or the hadith common link is a companion of the prophet, as many as 20 hadith $=30.3 \%$. (3) Hadith with the common link status carried by the Prophet, as many as 10 hadith $=15, \%$. (4) Hadiths that have a common link from successor at one tabaqah (level or lifetime) with Nāfi', as many as 4 hadiths $=6.1 \%$ and the total is $82.94 \%$; (5) Hadiths that have no common link in its isnad bundles. $17.06 \%$. Thus it is concluded that the transmission of Năfi' is reliable and he is credible in the narration of hadith from the Prophet.

\section{References}

Amin, Kamaruddin. (2009). Menguji Kembali Keakuratan Metode Kritik Hadīth . Jakarta: Hikmah.

Azami, M. (1968). Studies in Early Hadīth Literature. Beirut: al-Maktab al-Islam.

Azami, M. (2004). On Schacht's Origins of Muhammadan Jurisprudence. Lahore: Suhail Academy.

Ibn Hajar, a.-A. (1326). Tahdhīb al-Tahdhīb. India: Dāirah al-Ma'ārif al-Nizāamiyyah.

Ibn Șalāh, U. b. (1986). Ma'rifah anwā' 'Ulum al-Hadith. Bairut: Dār al-Fikr.

Juynboll, G.H.A. (1985). Muslim Tradition: Studies in Chronology provenance and Authorship of Early Hadith. Cambridge: Cambridge University Press.

Juynboll, G.H.A. (1996). Nāfi', the mawla of Ibn 'Umar, and His Position in Muslim Hadīth Literature. Der Islam, 207-244. 
Juynboll, G.H.A. (2001). (Re) Appraisal of Some Technical Terms in Hadīth Science. lslamic Law and Society, 8, 306.

Juynboll, G.H.A. (2007). Nāfi'. Encyclopedia of Canonical Hadīth, 876-877.

Masrur, Ali. (2007). Teori Common link G.H.A Juynboll: Melacak Akar Kesejarahan Hadis Nabi. Yogyakarta: LKIS.

Motzki, H. (2010). Analysing Muslim Traditions: Studies in Legal, Exegetical and Maghazi Hadith. BRILL, 78.

Muslim. (1993). Șahih Muslim. Bairut: Dar al-fikr.

Reinhart, A. K. (2010). Juynbolliana, Gradualism, the Big Bang, and Hadīth Study in the Twenty-First Century. Journal of the American Oriental Society, 130(3), 413444.

Schacht, J. (1950). The Origins of Muhammadan Jurisprudence. Oxford: Clarendon Press. 